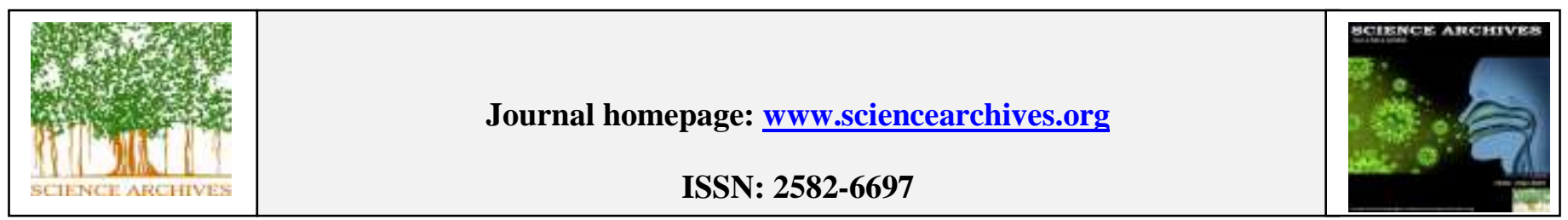

Research Article

http://dx.doi.org/10.47587/SA.2020.1203

\title{
Application of the sub-index model for valuation water quality for irrigation uses: A case study of groundwater in Al-Rashidiya area, North of Mosul city of Iraq
}

\author{
Abdulaziz. Y. T. Al-Saffawi ${ }^{\ltimes}$ and Ahmed J. A. Al-Barzanji \\ Dept. of Bio. Coll. of Edcation for pure Science \\ University of Mosul. Iraq. \\ Corresponding author $\vee<$ alsaffawia2025@uomosul.edu.iq \\ Received: Sept 06, 2020 / Accepted: Sept 24, 2020 / Published Date: Sept 29, 2020
}

\begin{abstract}
In the current study, wells water were assessed in Al-Rashidiya area located north of the left side of Mosul for irrigation, which is characterized by its agricultural nature and the abundance of fields and farms in it, was evaluated, One hundred water samples were taken from ten wells throughout the period from (October 2019 to mid-January 2020) to estimate some characteristics Physiochemical such as ph, Ec, and some negative and positive ions and irrigation parameters such as (SAR), (\% Na), (RSC), $(\mathrm{MH}),(\mathrm{PS}),(\mathrm{KR})$ and (PI), and the mathematical model was applied using eleven parameters to calculate IWQI values. The results of the IWQI values indicated that the water quality of the wells was of an excellent category for irrigation, as the values ranged between $(23,582$ to 30,429$)$. This improvement in quality is due to the fact that most of the studied parameters did not exceed the permissible confines for irrigation.
\end{abstract}

Keywords: Wells water of Al-Rashidiya area, IWQI, Water quality for irrigation

\section{Introduction}

The problem of environmental pollution, including water pollution, is today among the most important and sensitive issues in the world, so it was necessary to deal with it with the utmost seriousness because this problem is related to the existence of man, his health and his economy (Al-Shanona et al, 2018). The interest in securing and managing water resources is one of the basic pillars of national and national security, especially in arid and semi-arid regions, as well as countries whose water sources are from outside their borders, such as Iraq, and that one of the most important challenges facing Iraq, especially in recent years, is to achieve selfsufficiency in water resources that are a threat $\mathrm{He}$ has, in addition to other threats, such as climatic conditions, and countries that originate water sources from their lands trying to control, and exploit them politically and economically to achieve their goals. Upstream countries and resolving economically and politically outstanding problems, as well as urging for efficient management of Iraqi water resources by building service and scientific institutions and developing scientific and practical plans to solve problems related to water resource pollution and rationalizing water consumption (Bortolini et al, 2018; Al-Sardar and Saffawi, 2019). The lack of water is an increasingly important problem facing Iraq, As a result of the low levels from the Rivers of Tigris and Euphrates and most of the Iraqi tributaries, along with increasing salinity problems. Studies and reports indicate that Iraq may be exposed to serious water crises. Consequently, the main problem should not be left aside and interested in proposing non-economic projects and their results are negative for the country. Instead, scientific and practical solutions must be devised to address or mitigate the water scarcity crisis, which can be solved and by working hard with willpower and avoiding compliments in the implementation and enforcement of laws and because the water problem is mainly internal, there are some possible solutions that (Al-Hamdany et al., 2018: AlSaffawi, 2018a ) 
1. Rationing water consumption as traditional irrigation methods change.

2. Using the main principles of integrated and comprehensive management of water resources.

3. Constructing small dams on the flowing seasonal valleys to harvest and store rainwater, which has proven successful in many countries of the world.

\section{Material and Metheds}

\section{Description of the study area}

The study area located on the left side of the city of Mosul and northwest of Nineveh governorate and it is called AlRashidiya. The residents of the region are interested in agriculture and livestock breeding, where fields and farms are spread in the study area. So, ten wells were randomly chosen from the studied area and these wells are of surface type wells because their depths did not exceed twenty meters (AlHamdany et al., 2020a).

Table (1): Coordinates and characteristics of the studied wells.

\begin{tabular}{|c|c|c|c|c|}
\hline Wells & E & N & $\begin{array}{c}\text { Altitude } \\
(\mathrm{m})\end{array}$ & $\begin{array}{c}\text { Depth ( } \\
\mathrm{m})\end{array}$ \\
\hline 1 & $43^{\circ} 05^{\prime} 50^{\prime \prime}$ & $36^{\circ} 24^{\prime} 10^{\prime \prime}$ & 228 & 6.0 \\
\hline 2 & $43^{\circ} 05^{\prime} 43^{\prime \prime}$ & $36^{\circ} 24^{\prime} 01^{\prime \prime}$ & 227 & 7.0 \\
\hline 3 & $43^{\circ} 05^{\prime} 52^{\prime \prime}$ & $36^{\circ} 23^{\prime} 94^{\prime \prime}$ & 225 & 10 \\
\hline 4 & $43^{\circ} 05^{\prime} 12^{\prime \prime}$ & $36^{2} 24^{\prime} 01^{\prime \prime}$ & 225 & 10 \\
\hline 5 & $43^{\circ} 05^{\prime} 68^{\prime \prime}$ & $36^{\circ} 23^{\prime} 91^{\prime \prime}$ & 226 & 7.0 \\
\hline 6 & $43^{\circ} 05^{\prime} 74^{\prime \prime}$ & $36^{\circ} 24^{\prime} 01^{\prime \prime}$ & 224 & 8.0 \\
\hline 7 & $43^{\circ} 05^{\prime} 72^{\prime \prime}$ & $36^{\circ} 23^{\prime} 91^{\prime \prime}$ & 225 & 10 \\
\hline 8 & $43^{\circ} 05^{\prime} 79^{\prime \prime}$ & $36^{\circ} 23^{\prime} 97^{\prime \prime}$ & 224 & 12 \\
\hline 9 & $43^{\circ} 10^{\prime} 16^{\prime \prime}$ & $36^{\circ} 40^{\prime} 52^{\prime \prime}$ & 224 & 10 \\
\hline 10 & $43^{\circ} 06^{\prime} 12^{\prime \prime}$ & $36^{\circ} 23^{\prime} 92^{\prime \prime}$ & 222 & 4.0 \\
\hline
\end{tabular}

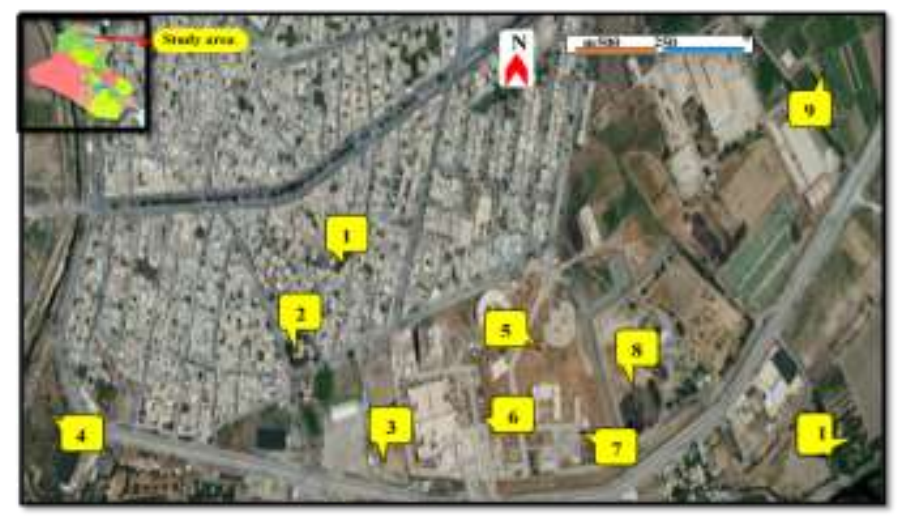

Fig 1: A map of the Al-ashidiya area showing the sites of studied wells.

\section{Geology of the study area}

Nineveh Governorate is characterized by the widespread formation of plasbi containing limestone $\mathrm{CaCO} 3$ and marl and Al-Fa'tha formation (middle myosin) that consists of limestone, salty rocks, gypsum $(\mathrm{CaSO} 4.2 \mathrm{H} 2 \mathrm{O})$, anhydrite (CaSO4) and marl, and this composition is spread in The northern parts of Iraq and the formation of Anjana (Upper Miocene) which consists of a succession of mud, sandstone, and marl, and these formations affect the quality of the water that passes through it (Al-Saffawi and Al-Shuuchi, 2018; AlYouzbaky et al., 2018).

\section{Methodology}

In the current study, 100 water samples were collected from ten randomly distributed wells in the region (from October 2019 to mid-January 2020), using polyethene bottles that were cleaned. It washed with distilled water and sampled water before filling (APHA, 1998). The well sites were loaded using the GPS for Google Earth and Fig. (1) shows the locations of the wells under study and table (1) showing the latitude, longitude, depth and Altitude of the studied wells. Analyzes of water samples were performed in the laboratories of the Department of Biology, College of Education for Pure Sciences, University of Mosul, to measure $\mathrm{pH}$, electrical conductivity, calcium , magnesium, sodium, potassium ions, chlorides, sulfates and bicarbonate according to international standard methods (APHA, 1998, 2017), and the irrigation water criteria were calculated as such sodium adsorption ratio (SAR), (\% Na), (RSC), (MH), (PS), (KR) and (PI) as from the following equations (Bhat et al, 2018; Al-Saffawi et al, 2019a ;Yasmin et al, 2019; Xu et al, 2019; Al-Saffawi et al, 2020a):

$$
\begin{gathered}
\mathrm{SSP}=(\mathrm{Na}+\mathrm{K}) \times 100 /(\mathrm{Ca}+\mathrm{Mg}+\mathrm{Na}+\mathrm{K}) \\
\mathrm{SAR}=[\mathrm{Na}] /\{(\mathrm{Ca}+\mathrm{Mg}) / 2\} 1 / 2 \\
\mathrm{PI}=[\mathrm{Na}+(\mathrm{HCO} 3) 1 / 2] \times 100 /(\mathrm{Ca}+\mathrm{Mg}+\mathrm{Na})] \\
\mathrm{RSC}=(\mathrm{CO} 3+\mathrm{HCO} 3)-(\mathrm{Ca}+\mathrm{Mg})
\end{gathered}
$$$$
1 / 2 \mathrm{SO} 4+\mathrm{Cl}=\mathrm{PS}
$$

$$
\mathrm{KR}=\mathrm{Na} /(\mathrm{Ca}+\mathrm{Mg})
$$

Where units are used with the meq. 1-1.

The quality of water used for irrigation was evaluated using internationally approved classifications such as the American Salinity Laboratory classification USDA and Donnen's classification referred to (Nag, and Das, 2014)for the combined effect of the concentration of chloride ions, sulfates, etc., the water quality index was (WQI) applied using eleven criteria: pH Ec, HCO3, Cl, KI, PI,\% Na, MH, RSC, SAR, PS. which was calculated using the following equation (Shobha, 2018; Al-Saffawi et al, 2020b; Chebet et al, 2020):

$$
\begin{gathered}
\mathrm{K}=1 / \sum_{i=1}^{n} \frac{1}{S \cdot p H}+\frac{1}{S . E c}+++ \\
\mathrm{Wn}=\mathrm{K} / \mathrm{Si} \\
\mathrm{qi}=100 \times[\mathrm{Vn}-\mathrm{Vi}] /[\mathrm{Si}-\mathrm{Vi}]
\end{gathered}
$$


$\mathrm{WQI}=\sum Q i \times \mathrm{Wn} / \sum \mathrm{Wn}$

Where:

$\mathrm{K}$ : the proportionality constant., Wn weight value for each property., Si: allowable standard concentration as shown in the table (2)., qi: quality rating of each parameter., Vn: measured value., Vi: ideal values Its equal to zero for all parameters except pH values equal to 7.0 ., WQI: Water Quality Index.

Table (2): Permissible limits(Si) and relative weight (Wn) values for studied irrigation parameters.

\begin{tabular}{|c|c|c|}
\hline Parameters & Standard limit $(\mathrm{Si})$ & Values of $(\mathrm{Wn})$ \\
\hline $\mathrm{pH}$ & $6.5-7.5$ & 0.076923000 \\
\hline $\mathrm{Ec}$ & 2000 & 0.000250000 \\
\hline $\mathrm{Cl}$ & 10 & 0.050000000 \\
\hline $\mathrm{HCO}_{3}$ & 8.5 & 0.058823500 \\
\hline $\mathrm{SAR}$ & 18 & 0.027777777 \\
\hline $\mathrm{RSC}$ & 2.25 & 0.222222222 \\
\hline $\mathrm{MH}$ & 50 & 0.010000000 \\
\hline$\% \mathrm{Na}$ & 60 & 0.008333333 \\
\hline $\mathrm{PS}$ & 10 & 0.050000000 \\
\hline $\mathrm{KR}$ & 1 & 0.500000000 \\
\hline $\mathrm{PI}$ & 75 & 0.006666660 \\
\hline \multicolumn{2}{|c|}{$\Sigma$} & 1.010996000 \\
\hline
\end{tabular}

After finding IWQI values, they are classified into five categories: Excellent Quality water (IWQI 0-25), good (IWQI 26-50), poor (IWQI 51-75), very poor (IWQI 76-100) and inadequate quality (IWQI >100) (KOÇ, 2018; Issa and Alrawi, 2018).

\section{Results \& Discussions}

The electrical conductivity expresses the quantity and quality of ions dissolved in water (APHA, 2017), and the results shown in Table (3) indicate that the values fluctuated between (1040 - 3712) $\mu \mathrm{S}$. cm-1, and these differences are By the character of the geological formations through which the water passes, because the groundwater passing through the layers rich in evaporation salts is characterized by high salts values in them (Al-Hamdany, et al, 2020b). These values are less than the values obtained by Al-Saffawi (2019) in its study of water wells of the Al-Nimrud region at southeastern of Mosul city of Mosul city, which did reach to (5110) $\mu \mathrm{S}$. m-1. The $\mathrm{pH}$ is an indicator of the amount of balance between acidity and water alkalinity. Groundwater values are affected by the nature and dissolution of salt and oxides in the ground rocks (Al-Saffawi and Al-Shuuchi, 2018). It is noted from the table 4 that the fluctuation in $\mathrm{pH}$ values, which ranged between (6.70 to 7.59), this is due to the ability of the Acid Neutralization Capacity (ANC) for Iraqi water and soil rich in bicarbonate and carbonate salts (Al-Saffawi and Talat, 2019). As for the relative decrease in values, it may be due to the presence of acid ions such as sulfates, nitrates and chlorides, and the occurrence of processes of decomposition and anaerobic biological oxidation of organic materials, which leads to the formation of many acidic compounds and carboxylic acids (Al-Saffawi, 2019).

This confirms the high concentrations of ions rates bicarbonates to reach $(8.24 \pm 1.02)$ meq. $1-1$ at the well No. 5 , and this rise is due to the dissolution of $\mathrm{CO} 2$ in rain water to form carbonic acid, which running to the geological layers containing dolomite rocks $(\mathrm{Ca} . \mathrm{MgCO} . \mathrm{nH} 2 \mathrm{O})$ and limestone $(\mathrm{CaCO} 3 . \mathrm{nH} 2 \mathrm{O})$ and interact with them to produce bicarbonates compounds as in the following equations: (AlSaffawi and Al-Sardar, 2018)

$$
\begin{aligned}
& \mathrm{H}_{2} \mathrm{O}+\mathrm{CO}_{2} \longleftrightarrow \mathrm{H}_{2} \mathrm{CO}_{3} \\
& \mathrm{CaCO}_{3}+\mathrm{H}_{2} \mathrm{CO}_{3} \longleftrightarrow \mathrm{Ca}^{+2}+2 \mathrm{HCO}^{-3} \\
& \mathrm{CaMgCO}_{3}+\mathrm{H}_{2} \mathrm{CO}_{3} \longleftrightarrow \mathrm{Ca}^{+2}+\mathrm{Mg}^{+2}+2 \mathrm{HCO}^{-3}
\end{aligned}
$$

For the same reasons for rising concentrations of calcium and magnesium ions to reach their averges to $(30.5 \pm 7.84)$ and $(20.3 \pm 7.23)$ meq. $1-1$ on the sequence. Thus, it reflected on the magnesium hazard $(\mathrm{MH})$ values, with rates ranging between (40 to 51), however, 90\% Samples are within allowable irrigation limits. Also, it is observed from the tables $(3,4)$ the fluctuation of sodium and potassium ions concentration, which ranged between (2.90 to 8.5) and (0.2 to 1.4) meq. 1-1 consecutively. This rise in calcium and magnesium concentrations compared to the bicarbonate, sodium and magnesium ions led to a decrease in the values of each of the (RSC), ), (\%Na), (SAR), (KR) and (PI), as it reached rates to $(0.0, \% 12.2,1.280 .22$ and 21.9$)$ on the sequence, which is within the permissible boundaries for irrigation (Moghimi, 2016). As for the values of P. Salinity, it is noticed from the tables $(3,4)$ that their levels rise to ranges between (15.7 to 25.6$)$ meq. $1-1$, thus the studied water is poor quality for irrigation of all types of soils according to the Doneen classification (Kablan, 2018). This deterioration in the quality of the water is due to the high chloride content and sulfates ions as a result of the presence of salt rocks, gypsum and anhydrite in the geological formations of the study area (Al-Hamdany et al, 2020a; Al-Saffawi et al 2020a) where the concentrations reached (13.4 and 46.1) meq. 1-1 consecutively.

\section{Water Quality Assessment for Irrigation}

Interpreting test results for irrigation water is not always an easy task. In most cases, among a large number of parameters used to describe the state of water quality for any water resource, there are some parameters within the permissible limits for irrigation, but others are not, and the overall quality of water is often vague. Therefore, modern methods such as water quality indicators (WQI) were used. It is a mathematical model that is used to convert large water quality data to a single number, representing interferences between all parameters used in the model, which facilitate the judgment on water quality. The water quality index results for the irrigation (IWQI) as shown in table (5) indicate that all studied well water was from the category of excellent quality irrigation water, where the values ranged between (23.582 to 30.429$)$ and this is due to the fact that most of the studied parameters were within the permissible limits for irrigation as previously described . 
Science Archives (2020) Vol. 1 (2), 61-67

Table 3: The extent, rate and standard deviation of the well water results in Al-Rashidiya area, Nineveh Governorate, Iraq.

\begin{tabular}{|c|c|c|c|c|c|c|c|c|c|c|c|}
\hline \multicolumn{2}{|c|}{$\begin{array}{l}\text { Wells } \\
\text { paramet. }\end{array}$} & 1 & 2 & 3 & 4 & 5 & 6 & 7 & 8 & 9 & 10 \\
\hline \multirow[t]{4}{*}{$\mathrm{pH}$} & $\min$ & 6.70 & 6.87 & 6.86 & 6.84 & 6.92 & 7.00 & 6.97 & 6.91 & 6.91 & 6.46 \\
\hline & $\max$ & 7.04 & 7.13 & 7.13 & 7.50 & 7.10 & 7.23 & 7.59 & 7.58 & 7.35 & 7.22 \\
\hline & mean & 6.88 & 6.96 & 6.97 & 7.02 & 7.01 & 7.13 & 7.28 & 7.11 & 7.12 & 6.97 \\
\hline & $\mathrm{Sd} \pm$ & 0.10 & 0.09 & 0.08 & 0.18 & 0.06 & 0.07 & 0.22 & 0.23 & 0.13 & 0.10 \\
\hline \multirow{4}{*}{$\begin{array}{l}\text { EC } \\
\mu S . m\end{array}$} & $\min$ & 2250 & 2146 & 2057 & 2240 & 2530 & 2681 & 2611 & 1040 & 2611 & 2680 \\
\hline & $\max$ & 2989 & 2622 & 3359 & 2613 & 2909 & 3510 & 3063 & 3712 & 3480 & 3380 \\
\hline & mean & 2769 & 2385 & 3061 & 2419 & 2721 & 3006 & 2812 & 2874 & 2921 & 3070 \\
\hline & $\mathrm{Sd} \pm$ & 216 & 171 & 392 & 127 & 140 & 256 & 155 & 973 & 275 & 215 \\
\hline \multirow{4}{*}{$\begin{array}{l}\mathrm{Cl} \\
\text { meq/l }\end{array}$} & $\min$ & 3.70 & 3.20 & 7.40 & 4.30 & 4.10 & 5.30 & 5.40 & 2.00 & 4.40 & 5.10 \\
\hline & $\max$ & 6.30 & 6.00 & 11.1 & 9.00 & 5.40 & 7.30 & 7.00 & 13.4 & 10.5 & 8.40 \\
\hline & mean & 5.40 & 5.00 & 10.0 & 5.60 & 5.00 & 6.50 & 6.20 & 8.80 & 6.30 & 7.10 \\
\hline & $\mathrm{Sd} \pm$ & 0.78 & 0.84 & 1.19 & 1.26 & 0.37 & 0.66 & 0.42 & 4.01 & 1.72 & 1.09 \\
\hline \multirow{4}{*}{$\begin{array}{l}\mathrm{HCO}_{3} \\
m e q / l\end{array}$} & $\min$ & 6.70 & 6.40 & 6.30 & 7.30 & 7.20 & 6.10 & 7.50 & 3.00 & 5.50 & 6.00 \\
\hline & $\max$ & 9.50 & 9.20 & 9.90 & 10.8 & 10.1 & 10.0 & 10.5 & 10.0 & 9.50 & 8.70 \\
\hline & mean & 7.17 & 7.25 & 7.53 & 8.15 & 8.24 & 7.56 & 8.34 & 6.47 & 7.10 & 6.83 \\
\hline & $\mathrm{Sd} \pm$ & 0.83 & 0.97 & 0.95 & 1.02 & 1.02 & 0.99 & 0.87 & 2.19 & 1.28 & 0.79 \\
\hline \multirow{4}{*}{$\begin{array}{l}\mathrm{SO}_{4} \\
\text { meq/l }\end{array}$} & $\min$ & 20.1 & 15.0 & 12.6 & 14.0 & 17.2 & 16.4 & 20.2 & 8.4 & 16.3 & 19.0 \\
\hline & $\max$ & 37.4 & 27.3 & 44.2 & 26.0 & 33.0 & 36.0 & 39.0 & 43.0 & 40.0 & 46.1 \\
\hline & mean & 24.7 & 22.0 & 30.4 & 19.9 & 24.6 & 27.9 & 26.9 & 26.9 & 26.9 & 31.4 \\
\hline & $\mathrm{Sd} \pm$ & 5.19 & 4.30 & 8.48 & 4.07 & 5.11 & 6.45 & 6.76 & 11.74 & 6.57 & 8.09 \\
\hline \multirow{4}{*}{$\begin{array}{l}\mathrm{Ca} \\
\text { meq/l }\end{array}$} & $\min$ & 24.4 & 15.6 & 23.6 & 14.4 & 17.2 & 20.0 & 12.4 & 5.0 & 12.8 & 18.0 \\
\hline & $\max$ & 35.2 & 23.1 & 49.0 & 21.0 & 33.2 & 37.2 & 38.7 & 51.2 & 52.3 & 32.5 \\
\hline & mean & 27.1 & 18.5 & 30.5 & 17.2 & 23.8 & 26.6 & 21.6 & 25.3 & 25.6 & 25.5 \\
\hline & $\mathrm{Sd} \pm$ & 3.18 & 2.59 & 7.84 & 2.46 & 5.64 & 4.63 & 7.59 & 16.85 & 11.62 & 4.78 \\
\hline \multirow{4}{*}{$\begin{array}{l}\mathrm{Mg} \\
\text { meq/l }\end{array}$} & $\min$ & 15.0 & 11.2 & 4.8 & 3.6 & 6.8 & 6.0 & 6.3 & 2.4 & 12.0 & 8.4 \\
\hline & $\max$ & 25.2 & 20.0 & 27.0 & 16.4 & 25.2 & 25.2 & 30.0 & 49.6 & 34.8 & 30.0 \\
\hline & mean & 18.6 & 15.1 & 20.3 & 13.1 & 17.7 & 18.0 & 21.9 & 21.1 & 18.6 & 19.9 \\
\hline & $\mathrm{Sd} \pm$ & 3.17 & 2.94 & 7.23 & 4.36 & 6.15 & 6.57 & 6.78 & 13.60 & 6.44 & 7.94 \\
\hline \multirow{4}{*}{$\begin{array}{l}\mathrm{Na} \\
\text { meq/l }\end{array}$} & $\min$ & 3.10 & 2.90 & 4.10 & 3.00 & 3.00 & 3.60 & 3.40 & 3.40 & 3.30 & 3.80 \\
\hline & $\max$ & 7.20 & 7.00 & 8.10 & 6.10 & 6.60 & 8.00 & 7.00 & 8.50 & 7.20 & 8.30 \\
\hline & mean & 5.15 & 4.85 & 6.34 & 4.69 & 4.89 & 5.54 & 5.34 & 5.72 & 5.41 & 6.10 \\
\hline & $\mathrm{Sd} \pm$ & 1.55 & 1.60 & 1.73 & 1.33 & 1.46 & 1.66 & 1.56 & 1.84 & 1.67 & 1.97 \\
\hline \multirow[t]{4}{*}{$\mathrm{K} m e q / l$} & $\min$ & 0.40 & 0.60 & 0.50 & 1.10 & 0.20 & 0.30 & 0.20 & 0.200 .50 & 0.20 & 0.20 \\
\hline & $\max$ & 1.00 & 1.30 & 1.10 & 1.80 & 0.60 & 0.80 & 0.50 & 0.38 & 1.40 & 0.60 \\
\hline & mean & 0.72 & 0.99 & 0.78 & 1.39 & 0.39 & 0.56 & 0.38 & 0.14 & 0.54 & 0.33 \\
\hline & $\mathrm{Sd} \pm$ & 0.22 & 0.28 & 0.19 & 0.21 & 0.15 & 0.21 & 0.15 & & 0.38 & 0.13 \\
\hline
\end{tabular}

\section{Conclusions \& Recommendations}

1. The studied water was characterized by the relative height of some studied parameters and for some periods such as electrical conductivity and latent salinity P. Salinity, calcium ions, magnesium sulfate, bicarbonate.

2. Because of the overlaps between these parameters, although most of them are within the upper limits allowed for irrigation; As $100 \%$ of the IWQI values were of good quality for irrigation.

Therefore, we recommend conducting periodic tests of resources with emphasis on using mathematical models to find the IWQI values because knowing these values for any water resource will help water officials and policymakers explain the groundwater quality conditions to take appropriate action.

\section{Acknowledgment}

The researchers extend their thanks and gratitude to the presidency of Mosul University / Iraq, represented by Prof .Dr. Qusay Kamal Al-Din Al-Ahmadi for the facilities provided to researchers and the provision of all the requirements of scientific research, as well as the Deanship of the College of Education for Pure Sciences and the departments of Biology and Chemistry to facilitate work in their laboratories and provide all research requirements. 
Science Archives (2020) Vol. 1 (2), 61-67

Table 4: the extent, rate and standard deviation of the well water results in Al-Rashidiya area, Nineveh Governorate, Iraq

\begin{tabular}{|c|c|c|c|c|c|c|c|c|c|c|c|}
\hline \multicolumn{2}{|c|}{$\begin{array}{l}\text { Wells } \\
\text { Paramet. }\end{array}$} & 1 & 2 & 3 & 4 & 5 & 6 & 7 & 8 & 9 & 10 \\
\hline \multirow[t]{4}{*}{ SAR } & $\min$ & 0.70 & 0.70 & 0.80 & 0.80 & 0.70 & 0.80 & 0.80 & 0.80 & 0.60 & 0.80 \\
\hline & $\max$ & 1.50 & 1.60 & 1.60 & 1.50 & 1.40 & 1.80 & 1.50 & 2.00 & 1.60 & 1.90 \\
\hline & mean & 1.08 & 1.17 & 1.27 & 1.21 & 1.06 & 1.19 & 1.13 & 1.24 & 1.16 & 1.28 \\
\hline & $\mathrm{Sd} \pm$ & 0.30 & 0.37 & 0.33 & 0.28 & 0.28 & 0.36 & 0.28 & 0.37 & 0.36 & 0.36 \\
\hline \multirow[t]{4}{*}{ RSC } & $\min$ & -45.0 & -3.01 & -49.0 & -26.0 & -39.0 & -45.0 & -42.0 & -60.0 & -58.0 & -47.0 \\
\hline & $\max$ & -9.20 & -2.00 & -38.0 & -11.0 & -18.0 & -23.0 & -22.0 & -12.0 & -24.0 & -26.0 \\
\hline & mean & -36.0 & -26.0 & -43.0 & -22.0 & -33.0 & -37.0 & -35.0 & -40.0 & -37.0 & -39.0 \\
\hline & $\mathrm{Sd} \pm$ & 10.0 & 3.23 & 3.52 & 5.03 & 6.42 & 7.13 & 6.19 & 15.8 & 9.08 & 7.42 \\
\hline \multirow[t]{4}{*}{ MH } & $\min$ & 30.0 & 34.0 & 8.90 & 20.0 & 25.0 & 20.0 & 14.0 & 5.00 & 22.0 & 26.0 \\
\hline & $\max$ & 48.0 & 53.0 & 52.0 & 53.0 & 57.0 & 50.0 & 71.0 & 74.0 & 73.0 & 61.0 \\
\hline & mean & 41.0 & 45.0 & 40.0 & 42.0 & 42.0 & 40.0 & 51.0 & 49.0 & 44.0 & 43.0 \\
\hline & $\mathrm{Sd} \pm$ & 5.30 & 5.80 & 14.1 & 10.3 & 11.8 & 11.1 & 14.6 & 25.0 & 15.7 & 13.1 \\
\hline \multirow{4}{*}{$\% \mathrm{Na}$} & $\min$ & 7.0 & 8.0 & 7.6 & 8.6 & 6.9 & 7.3 & 7.6 & 7.0 & 5.2 & 7.3 \\
\hline & $\max$ & 13.0 & 15.0 & 13.3 & 15.5 & 13.0 & 18.8 & 14.1 & 19.1 & 15.0 & 19.0 \\
\hline & mean & 9.84 & 12.2 & 10.9 & 12.9 & 10.5 & 11.0 & 10.7 & 12.2 & 11.1 & 11.9 \\
\hline & $\mathrm{Sd} \pm$ & 2.24 & 2.75 & 2.38 & 2.35 & 2.10 & 3.47 & 2.07 & 4.36 & 3.20 & 3.21 \\
\hline \multirow[t]{4}{*}{ PS } & $\min$ & 14.2 & 14.2 & 15.0 & 11.8 & 12.7 & 13.5 & 16.1 & 6.2 & 14.2 & 15.9 \\
\hline & $\max$ & 24.0 & 19.1 & 33.1 & 20.0 & 22.5 & 32.2 & 26.5 & 34.5 & 25.0 & 31.3 \\
\hline & mean & 17.8 & 16.5 & 25.6 & 15.7 & 17.5 & 21.4 & 20.2 & 22.9 & 19.8 & 23.1 \\
\hline & $\mathrm{Sd} \pm$ & 2.70 & 1.56 & 4.65 & 2.73 & 2.97 & 5.18 & 3.51 & 9.96 & 3.20 & 4.78 \\
\hline \multirow[t]{4}{*}{ KR } & $\min$ & 0.08 & 0.09 & 0.08 & 0.09 & 0.07 & 0.07 & 0.08 & 0.07 & 0.05 & 0.08 \\
\hline & $\max$ & 0.15 & 0.96 & 0.16 & 0.19 & 0.15 & 0.23 & 0.16 & 0.24 & 0.18 & 0.24 \\
\hline & mean & 0.12 & 0.22 & 0.12 & 0.15 & 0.11 & 0.12 & 0.12 & 0.14 & 0.12 & 0.13 \\
\hline & $\mathrm{Sd} \pm$ & 0.02 & 0.26 & 0.03 & 0.04 & 0.03 & 0.05 & 0.03 & 0.06 & 0.05 & 0.05 \\
\hline \multirow[t]{4}{*}{ PI } & $\min$ & 13.0 & 16.1 & 13.0 & 17.0 & 12.8 & 12.4 & 14.2 & 10.4 & 10.0 & 12.0 \\
\hline & $\max$ & 18.1 & 22.1 & 18.2 & 27.0 & 20.4 & 26.4 & 20.0 & 28.0 & 20.4 & 25.0 \\
\hline & mean & 15.3 & 19.5 & 15.9 & 21.9 & 16.9 & 16.8 & 17.0 & 17.8 & 16.7 & 17.1 \\
\hline & $\mathrm{Sd} \pm$ & 1.89 & 2.12 & 2.11 & 2.82 & 2.21 & 3.91 & 1.90 & 5.90 & 3.20 & 3.40 \\
\hline
\end{tabular}

Table 5: Weight value(Wn), quality rating (qi) of each parameter and water quality Index (WQI)

\begin{tabular}{|r|r|c|c|c|c|c|c|c|c|c|c|}
\hline Wells & Paramet. & 1 & 2 & 3 & 4 & 5 & 6 & 7 & 8 & 9 & 10 \\
& & & & & & & & & & & \\
\hline $\mathrm{pH}$ & $\mathrm{qn}$ & 24.000 & 8.0000 & 8.0000 & 4.0000 & 2.0000 & 26.000 & 56.000 & 22.000 & 24.000 & 6.0000 \\
& $\mathrm{qn} \times \mathrm{Wn}$ & 1.8456 & 0.6152 & 0.6152 & 0.3076 & 0.1538 & 1.9994 & 4.3064 & 1.6918 & 1.8456 & 0.4614 \\
\hline $\mathrm{EC}$ & $\mathrm{qn}$ & 139.00 & 119.00 & 153.00 & 121.00 & 136.00 & 150.00 & 141.00 & 144.00 & 146.00 & 154.00 \\
& $\mathrm{qn} \times \mathrm{Wn}$ & 0.0417 & 0.0357 & 0.0459 & 0.0363 & 0.0408 & 0.045 & 0.0423 & 0.0432 & 0.0438 & 0.0462 \\
\hline $\mathrm{Cl}$ & $\mathrm{qn}$ & 54.000 & 50.000 & 100.00 & 56.000 & 50.000 & 65.000 & 62.000 & 88.000 & 63.000 & 71.000 \\
& $\mathrm{qn} \times \mathrm{Wn}$ & 2.7000 & 2.5000 & 5.0000 & 2.8000 & 2.5000 & 3.2500 & 3.1000 & 4.4000 & 3.1500 & 3.5500 \\
\hline $\mathrm{HCO}_{3}$ & $\mathrm{qn}$ & 000.84 & 85.000 & 89.000 & 96.000 & 97.000 & 89.000 & 98.000 & 76.000 & 84.000 & 80.000 \\
& $\mathrm{qn} \times \mathrm{Wn}$ & 4.9392 & 4.9980 & 5.2332 & 5.6448 & 5.7036 & 5.2332 & 5.7624 & 4.4688 & 4.9392 & 4.704 \\
\hline $\mathrm{SAR}$ & $\mathrm{qn}$ & 6.0000 & 6.5000 & 7.1000 & 6.7000 & 5.9000 & 6.6000 & 6.3000 & 6.9000 & 6.4000 & 7.1000 \\
& $\mathrm{qn} \times \mathrm{Wn}$ & 0.1668 & 0.1807 & 0.1974 & 0.1863 & 0.1640 & 0.1835 & 0.1751 & 0.1918 & 0.1779 & 0.1974 \\
\hline $\mathrm{RSC}$ & $\mathrm{qn}$ & 0.0000 & 0.0000 & 0.0000 & 0.0000 & 0.0000 & 0.0000 & 0.0000 & 0.0000 & 0.0000 & 0.0000 \\
& $\mathrm{qn} \times \mathrm{Wn}$ & 0.0000 & 0.0000 & 0.0000 & 0.0000 & 0.0000 & 0.0000 & 0.0000 & 0.0000 & 0.0000 & 0.0000 \\
\hline $\mathrm{MH}$ & $\mathrm{qn}$ & 81.500 & 90.000 & 80.200 & 84.000 & 84.400 & 79.000 & 102.00 & 98.400 & 87.200 & 85.300 \\
& $\mathrm{qn} \times \mathrm{Wn}$ & 0.8150 & 0.9000 & 0.8020 & 0.8400 & 0.8440 & 0.7900 & 1.0200 & 0.9840 & 0.8720 & 0.8530 \\
\hline$\% \mathrm{Na}$ & $\mathrm{qn}$ & 16.400 & 20.300 & 18.100 & 21.500 & 17.500 & 18.400 & 18.000 & 20.400 & 18.500 & 20.000 \\
& $\mathrm{qn} \times \mathrm{Wn}$ & 0.1361 & 0.1685 & 0.1502 & 0.1785 & 0.1453 & 0.1527 & 0.1494 & 0.1693 & 0.1536 & 0.166 \\
\hline $\mathrm{P} . \mathrm{S}$ & $\mathrm{qn}$ & 178.30 & 165.30 & 256.00 & 157.00 & 175.00 & 214.30 & 202.10 & 228.50 & 198.00 & 231.40 \\
& $\mathrm{qn} \times W n$ & 8.9150 & 8.2650 & 12.800 & 7.8500 & 8.7500 & 10.715 & 10.105 & 11.425 & 9.9000 & 11.570 \\
\hline
\end{tabular}


Science Archives (2020) Vol. 1 (2), 61-67

\begin{tabular}{|r|r|l|l|l|l|l|l|l|l|l|l|}
\hline KR & qn & 11.600 & 22.300 & 12.100 & 14.900 & 11.200 & 12.300 & 11.600 & 13.800 & 11.900 & 13.100 \\
& qn×Wn & 5.8000 & 11.150 & 6.0500 & 7.4500 & 5.6000 & 6.1500 & 5.8000 & 6.9000 & 5.9500 & 6.5500 \\
\hline PI & qn & 20.400 & 26.000 & 21.200 & 29.200 & 22.500 & 22.400 & 22.600 & 23.700 & 22.300 & 22.800 \\
& $\mathrm{qn} \times W n$ & 0.1367 & 0.1742 & 0.1420 & 0.1956 & 0.1508 & 0.1501 & 0.1514 & 0.1588 & 0.1494 & 0.1528 \\
\hline & $\Sigma \mathrm{qn} \times \mathrm{Wn}$ & 25.496 & 28.987 & 31.036 & 25.489 & 24.052 & 28.669 & 30.612 & 30.433 & 27.182 & 28.251 \\
\hline WQI & 24.997 & 28.420 & 30.429 & 24.990 & 23.582 & 28.108 & 30.013 & 29.837 & 26.650 & 27.698 \\
\hline \multicolumn{2}{|r|}{ Wat. Quality } & Excell. & Excell. & Excell. & Excell. & Excell & Excell & Excell & Excell & Excell & Excell \\
\hline
\end{tabular}

\section{Conflict of Interest}

Authors hereby declare no conflict of interest.

\section{References}

Al-Hamdany, I. O. S., Al-Saffawi. A. Y. T. and Kaplan, A. Y. (2018). Application of the Canadian model for evaluating groundwater for irrigation and livestock watering : Case study: well water of Al-Sideq and Al-Hadba sectors in Mosul City. Accepted for publication in the Proceedings of the First Int. Conf. \& 3rd Scientific of Faculty of Sci., Uni. of Tikret, Iraq. 17-18.

Al-Hamdany, N. A. S., Al-Saffawi, A. Y. T. and Al-Shaker, . M. S. (2020b). Applying the sub-index model to evaluate the quality of water for irrigation purposes , Case study: wells water of left side From Mosul city. Iraq. (under publication).

Al-Hamdany, N. A. S., Al-Shaker, Y.M. S. and Al-Saffawi, A. Y. T. (2020a). Water quality assessment using the NSFWQI model for drinking and domestic purposes: A case study of groundwater on the left side of Mosul city. Iraq. Plant Archives. 20(1): 3079-3085.

Al-Saffawi, A. Y. T. (2019). Water qualityindex assessment of ground water in Al- Nimrud district of Southeastern Mosul City. Iraq. Pakistan J.of Analytical Chemi. \& $\begin{array}{lll}\text { Envi. } & \text { Sci. } & \text { 20(1): }\end{array}$ doi.org/10.21743/pjaec/2019.06.10

Al-Saffawi, A. Y. T. and Talat, R. A. (2019).Using water quality model (IWQI) to assess the reality of water wells Hamdania products in Ninawa Governorate.

Al-Saffawi, A. Y., Al Sinjari, W. E. and Al-Taee, Y. A. (2019a). Application of WQI model to assessment of water dor irrigation and livestock drinking purpose: The case study, ground water quality of Gleewkhan village southeastern of Mosul city, Iraq. J. Eng. Applied Sci., 14 (Special Issue 9): 10706-10710.

Al-Saffawi, A.Y.T. (2018a). Assessment of groundwater for irrigation and domestic suitability by using (WQI) in Singiar district eastern of Mosul city. Iraq. Mesopo. Environ. j., Special Issue F., 75-84. http: www.bumej.com.

Al-Saffawi, A.Y.T. and Y.A.M. Al-Shuuchi (2018). Assessment of groundwater quality for irrigation by using water quality index(IWQ index) in Al- Kasik district Northeastern of Mosul City. Iraq. Int. J. of Enhanced Res. in Sci., Techn. and Engin., 7(1): 76-81. http://www.erpublications.com.

Al-Saffawi, A.Y.T., Al-Asaaf, A. Y.R. and Talat, R. A. (2020b). Valuation of water quality for livestock and poultry watering: a case study of groundwater in some areas of Mosul city, Iraq. Nipp. J. Env. Sci., 1(2): 1-7. https://doi.org/10.46266/njes.1006
Al-Saffawi, A.Y.T., Ibn Abubakar, B. S. U., Abbass, L. Y. and Monguno, A. K. (2020a). Assessment of groundwater quality for irrigation using water quality index (IWQ Index) in Alkasik subdistrict northwestern of Iraq. Nigerian J. of Tech. (NIJOTECH). 39(2): $632-638$. http://dx.doi.org/10.4314/njt.v39i1.35

Al-Yousbakey, K.T., A.M. Sulaiman and D.A. Ismaeel (2018). The evalution of chemical characterization for selected wells water in Mosul-Bahshiqa-Shalalat areas, Ninivah governorate, Northern Iraq. The 9th periodical Sci. Confer. of dam and water resources Res. Center. Mosul Univer. Iraq. 28-29 Nov. 2018, 201-216.

angalore, India. American J. of Civil and Env. Eng. 3(4): 68-82. http://www.aascit.org/journal/ajcee

APHA. (1998). Standard method for the examination of water and waste water. American Public Health Association (20th ed.) Washington D.C, USA.

APHA. (2017). Standard Method for Examination of water and wastewater. American public Health Association, 23th ed., Washington, DC, USA.

Bhat, M. A., Wani, S. A., Singh, V. K., Sahoo, J.,Tomar, D. and Sanswal, R. (2018). An overview of the assessment of groundwater quality for irrigation. J. Agri. Sci. Food Res. 9(1):1-9. https://www.researchgate.net/publication/324536967

Chebet, E. C., Kibet, J. K. and Damaris Mbui, D. (2020). The assessment of water quality in river Molo water basin, Kenya. Applied Water Science. 10:92.-102. https://doi.org/10.1007/s13201-020-1173-8

irrigation, Iraq. International Journal of Environment \& Water. 8(4): 75-84.

Issa, H. M. and Alrawi, R. A. (2018). Long-term drinking water quality assessment using index and multivariate statistical analysis for three water treatment plants of Erbil city, Iraq. UKH Journal of Science and Engineering 2(2): 3948.

Kablan, A. Y. H. (2018). Qualitative status assessment of groundwater of some quarters of Mosul city by using water quality index models (WQI). MSC thesis. College of Science, University of Tikrit. Iraq.

KOÇ, C. (2018). Water quality index for measuring drinking water quality of bodrum peninsula-Turkey. ÖHÜ Müh. Bilim. Derg. / OHU J. Eng. Sci., 2018, 7(2): 694-702. doi: 10.28948/ngumuh.444731

Moghimi, H. (2016). The Assessment of Groundwater Resources for Irrigation by Water Quality Indices (Case Study, Ghazvin Plain, Northwest of Iran). The Caspian Sea Journal.10(1):538-548.

Nag, S.K. and S. Das (2014). Quality assessment of groundwater with special emphasis on irrigation and domestic suitability in Suri I\&II block, Birbhum district, west Bengal, India. Amer. J. Wat. Reso., 2(4): 81-98. 


\section{Science Archives (2020) Vol. 1 (2), 61-67}

Shobha, B. S. (2018). A comprehensive assessment of spatial interpolation method using IDW technique for the

Xu, P., Feng, W., Qian, H. and Zhang, Q. (2019). Hydrogeochemical Characterization and Irrigation Quality Assessment of Shallow Groundwater in the Central-Western Guanzhong Basin, China. Int. J. Environ. Res. Public Health. 16(1492): 1-18. www.mdpi.com/journal/ijerph

\section{How to cite this article:}

Al-Saffawi, A.Y. T. and Al-Barzanji A.J.A. (2020) Application of the sub-index model for valuation water quality for irrigation uses: A case study of groundwater in Al-Rashidiya area, North of Mosul city of Iraq Science Archives, Vol. 1 (2), 61-67.

http://dx.doi.org/10.47587/SA.2020.1203 groundwater quality evaluation of an industrial area in

Yasmin, G., Islam, D., Islam, M. T., Ullah, M. S. and A K M Adham, A. K. M. (2019). Evaluation of groundwater quality for irrigation and drinking purposes in Barishal district of Bangladesh. Fund. and Appl. Agric. 4(1): 632641. doi: $10.5455 /$ faa. 301258

This work is licensed under a Creative Commons Attribution 4.0 International License.

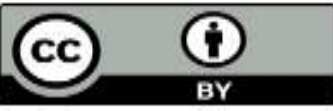

